\title{
Epidemiologi ved blandet bindevevsykdom, mixed connective tissue disease (MCTD) hos barn
}

\author{
Odd Vinje og Berit Flatø \\ Revmatologisk avdeling, Rikshospitalet
}

\section{ENGLISH SUMMARY}

\author{
Vinje O, Flatø B. The epidemiology of mixed connective tissue disease in children. \\ Nor J Epidemiol 2008; 18 (1): 86-88.
}

\begin{abstract}
There are three different classification criteria for this disease, all from 1987: The Alarcon-Segovia, Sharp and Kasukawa criteria. There is still no international concensus as to which of them should be used. This makes comparison between different reports using different classification criteria difficult. Mixed connective tissue disease seems next to systemic sclerosis to be the most infrequent systemic connective tissue disease in children. The incidence is reported to amount to $0.1-0.3 / 100,000 /$ year. Female/male ratio is reported to be 2-3/1, median age for disease debut about 11 years, range $4-16$ years. The most frequent cause of death is probably pulmonary hypertension, but death because of sepsis, hearth failure, renal failure, CNS disease and gastrointestinal bleeding is also reported. Mortality rate is probably lower in mixed connective tissue disease with debut in childhood than in adult life.
\end{abstract}

MCTD er en autoimmun, multiorgansykdom av ukjent årsak med symptomer og funn fra minst to andre revmatiske sykdomsgrupper: juvenil idiopatisk artritt (JIA), juvenil SLE (JSLE), juvenil dermatomyositt (JDM) og systemisk sklerose. MCTD ble første gang beskrevet av Sharp og medarbeidere i 1972 (1).

\section{KLASSIFIKASJON/DIAGNOSE}

Det finnes i dag ingen konsensus på bredt internasjonalt aksepterte klassifikasjons- eller diagnostiske kriterier for MCTD. Dette skaper usikkerhet fordi ulike kriterier er brukt i ulike studier. Dette gjør sammenligning vanskelig. Tre sett med diagnostiske kriterier er mest brukt i klinisk forskning. De er utarbeidet av Alarcón-Segovia og Villareal (2), Sharp og medarbeidere (3), og av Kasukawa og medarbeidere (4).

\section{Alarcón-Segovia og Villareal kriteriene for MCTD fra 1987}

Det kreves RNP positivitet pluss minst 3 kliniske kriterier. Hvis 1, 2 og 3 er positive, kreves 4 eller 5 i tillegg.

1. Håndødem

2. Synovitt

3. Myositt

4. Raynauds fenomen

5. Akrosklerose

\section{Sharps kriterier for MCTD fra 1987}

Det kreves 4 majorkriterier og anti U1RNP eller 2 majorkriterier (av 1, 2 og 3) og 2 minorkriterier med anti-U1 RNP.

\section{A. Majorkriterier}

1. Myositt (alvorlig)

2. Lungeaffeksjon

a. CO diffusjonskapasitet $<70 \%$ av normal

b. Pulmonal hypertensjon

c. Proliferative vaskulær lesjon i lungebiopsi

3. Raynauds fenomen eller øsofagus-dysmobilitet

4. Hovne hender eller sklerodaktyli

5. Høytitret ENA og anti-RNP og negativ anti-Sm

\section{B. Minorkriterier}

1. Alopeci

2. Leukopeni

3. Anemi

4. Pleuritt

5. Pericarditt

6. Artritt

7. Trigeminus nevralgi

8. Malart utslett

9. Trombocytopeni

10. Myositt (mild)

11. Hovne hender i løpet av sykdomsforløpet

\section{Kasukawa og medarbeidere (JMHW) kriterier for MCTD fra 1987}

Minst en 1 av de 2 hyppige symptomene pluss påvisning av anti-snRNP antistoff pluss en eller flere av de blandete symptomene i minst 2 av de 3 undergruppene må være oppfylt.
A: Hyppige symptomer
1. Raynauds fenomen
2. Hovne fingrer eller hånd 


\section{B: Påvist anti-snRNP antistoff}

C: Blandete symptomer

1. SLE-lignende funn
a. Polyartritt
b. Lymfadenopati
c. Ansikt-erytem
d. Perikarditt eller pleuritt
e. Leuko- og/eller trombocytopeni

2. SSc-lignende funn
a. Sklerodaktyli
b. Lungefibrose, restriktive lungeforandringer, eller redusert diffusjonskapasitet
c. Minsket motilitet eller utvidet øsofagus
3. PM-lignende funn
a. Muskelsvakhet
b. Forhøyete muskelenzymer (CPK)
c. Myogent mønster ved EMG

\section{FOREKOMST}

Usikkert både når det gjelder barn og voksne, men trolig nest etter systemisk sklerose den sjeldneste bindevevssykdom hos barn. I en prospektiv nasjonal finsk studie (5) er det rapportert en årlig insidens på 0,1\% og fra database i USA (6) en insidens på 0,3/100.000 barn. Median sykdomsdebut er på omtrent 11 år fordelt mellom 4 og 16 år. Man finner overvekt av piker 2-3/1. Kun en rapport har beskrevet sykdom hos søsken (7).

\section{Prognose/MORTAlitet}

Sykdomsutviklingen er uforutsigbar og svært forskjellig fra person til person. Michels og medarbeidere (8) rapporterte i 1997 sykdomsforløpet hos totalt 224 pasienter med juvenil MCTD. Av disse var 191 det totale antall pasienter tilgjengelige i litteraturen frem til 1996, de øvrige 33 var egne pasienter fulgt opp i Garmisch Partenkirchen fra 1976. Metaanalyser indikerte at de fleste av barna etter hvert ble bedre av sykdommen. Remisjon opptrådte hos 3-27\%. Kliniske symptomer og funn med lang varighet er: artritt opp til $97 \%$, Raynaud-fenomener og sklerodermilignende hudforandringer opp til 86\%, restriktiv lungesykdom opp til $57 \%$, nyresykdom opp til $47 \%$ og esofagusdysmobilitet og innskrenket leddbevegelighet begge opp til 29\%. Hjerteaffeksjon, kardiomyopati eller perikarditt var meget sjeldent, men dersom til stede ofte forbundet med dårlig prognose. Totalt 17 pasienter (7,6\%) ble rapportert døde: sepsis 7, CNS-affeksjon 3, hjertesvikt 2, pulmonal hypertensjon 2, nyresvikt 2 og GI blødning 1.

Kotajima og medarbeidere (9) sammenlignet to grupper med MCTD: gruppe 1: sykdomsdebut $<16$ år, gruppe 2: sykdomsdebut 16 år eller eldre. Mortalitet var sjeldnere ved juvenil MCTD, henholdsvis 2,8\% versus $8,4 \%$ hos dem med debut i voksen alder.

Burdt og medarbeidere (10) beskriver sykdomsforløpet hos 47 voksne og barn som ble fulgt over 3-29 år. De fant at tegn til inflammasjon, Raynaudfenomener og esofagus-dysmobilitet ble mindre med årene mens pulmonal hypertensjon, nedsatt lungefunksjon og affeksjon av CNS persisterte etter behandling. Sklerodaktyli var hyppig, 49\%. Diffus sklerose ble funnet hos $19 \%$ av pasientene. $62 \%$ hadde en fordelaktig sykdomsutvikling mens $38 \%$ fortsatte å ha aktiv sykdom eller var døde. 11 pasienter var døde etter 3 til 25 års sykdom. Ni av disse hadde pulmonal hypertensjon med hyppig samtidig tilstedeværelse av antikardiolipin-antistoffer.

\section{KONKLUSJON}

MCTD er trolig den sjeldneste bindevevssykdommen hos barn nest etter systemisk sklerose. Det er ingen generell konsensus når det gjelder klassifikasjonskriterier. Dette gjør det vanskelig å sammenligne resultater som benytter ulike kriterier. Hyppigste dødsårsak er trolig pulmonal hypertensjon, men det er også beskrevet dødsfall på grunn av sepsis, hjertesvikt, nyresvikt, CNS-affeksjon og gastrointestinal blødning. Trolig er mortalitet som skylles grunnsykdommen lavere ved MCTD med juvenil enn med adult debut.

\section{REFERANSER}

1. Sharp GC, Irvin WS, Tan EM et al. Mixed connective tissue disease - an apparently distinct rheumatic disease syndrome associated with a specific antibody to an extractable nuclear antigen (ENA). Am J Med 1972; 52: 148-59.

2. Alarcon-Segovia D, Villareal M. Classification and diagnostic criteria for mixed connective tissue disease. In: Kasukawa R, Sharp GC, editors. Mixed connective tissue disease and antinuclear antibodies. Amsterdam: Elsevier, 1987: 33-40.

3. Sharp GC. Diagnostic critera for classification of MCTD. In: Kasukawa R, Sharp GC, editors. Mixed connective tissue disease and antinuclear antibodies. Amsterdam: Elsevier, 1987: 23-30.

4. Kasukawa R, Tojo T, Miyawaki S. Preliminary diagnostic criteria for classification of mixed connective tissue disease. In: Kasukawa R, Sharp GC, editors. Mixed connective tissue disease and antinuclear antibodies. Amsterdam: Elsevier, 1987: 41-7. 
5. Pelkonen PM, Jalanko HJ, Lantto RR et al. Incidence of systemic connective tissue disease in children: a nationwide prospective study in Finland. J Rheumatol 1996; 21: 2143-6.

6. Bowyer S, Roettcher P. Pediatric rheumatology clinic populations in the United States: results of a 3 year survey. Pediatric Rheumatology Database Research Group. J Rheumatol 1996; 23: 1968-74.

7. Horn JR, Kapur JJ, Walker SE. Mixed connective tissue disease in siblings. Arthritis Rheum 1978; 21: 70914.

8. Michels H. Course of mixed connective tissue disease in children. Ann Med 1997; 29: 359-64.

9. Kotajima L, Aotsuka S, Sumiya M et al. Clinical features of patients with juvenile onset mixed connective tissue disease: analysis of data collected in a nationwide collaborative study in Japan. J Rheumatol 1996; 23: 1088-94.

10. Burdt MA, Hoffman RW, Deutscher SL et al. Long-term outcome in mixed connective tissue disease: longitudinal clinical and serologic findings. Arthritis Rheum 1999; 42: 899-909. 